\title{
PENINGKATAN PEMAHAMAN MASYARAKAT TERHADAP COVID-19 DI BTN GRIYA NUGRATAMA CIANJUR JAWA BARAT
}

\author{
Fransiska Puspita Dewi ${ }^{1}$, Syamsul Hadi ${ }^{2}$ \\ ${ }^{1}$ Ilmu Teknologi Pangan Fakultas Pertanian Universitas Sebelas Maret \\ ${ }^{2}$ Teknik Mesin Fakultas Teknik Universitas Sebelas Maret \\ syamsulhadi@ft.uns.ac.id
}

\begin{abstract}
Kuliah Kerja Nyata (KKN) UNS Tanggap Covid-19 in BTN Griya Nugratama, Cianjur, West Java is a community service activity by Sebelas Maret University students to accelerate the handling of the Covid-19 pandemic that is hitting various countries, including Indonesia. Implementation of KKN UNS Tanggap Covid-19 is expected to develop practical skills of students in helping to resolve the issues or problems that occurred in the community during pandemic. The main programs of KKN UNS Tanggap Covid-19 at BTN Griya Nugratama RT05/RW14 are online socialization about Covid-19 with informative and educational infographics and poster through social media, making and distributing hand sanitizers with recommended use by WHO; the secondary programs are video making of jamu (traditional drink), and participating in Covid-19 online volunteer. The implementation of the KKN UNS Tanggap Covid-19 went smoothly and all KKN program activities at BTN Griya Nugratama RT05 / RW14 have been carried out as expected. The community also actively participates and appreciates KKN activities as well.
\end{abstract}

Keywords: KKN UNS, COVID-19, Body Immunity

\section{PENDAHULUAN}

Coronavirus adalah sekumpulan virus dari subfamili Orthocronavirinae dalam keluarga Coronaviridae dan ordo Nidovirales. Coronavirus pada manusia, menyebabkan infeksi saluran pernapasan yang umumnya ringan, seperti pilek, meskipun beberapa bentuk penyakit seperti SARS, MERS, namun Covid-19 sifatnya lebih mematikan. Virus Corona pada saat ini, bukanlah suatu wabah yang bisa diabaikan begitu saja. Jika dilihat dari gejalanya, orang awam akan mengiranya hanya sebatas influenza biasa, tetapi bagi analisis kedokteran virus ini cukup berbahaya dan mematikan. Saat ini di tahun 2020, perkembangan penularan virus ini cukup signifikan karena penyebarannya sudah mendunia dan seluruh negara merasakan dampaknya termasuk Indonesia (Yunus dkk., 2020).

Dalam kasus wabah Covid-19 yang terpapar hampir di seluruh negara di dunia, adalah permasalahan kemanusiaan yang mempengaruhi seluruh aspek kehidupan manusia. Indonesia sebagai salah satu negara yang terdampak Covid-19 dan telah menyatakan sebagai Kejadian Luar Biasa (KLB) mulai bulan Maret 2020. Kondisi yang semakin parah, membuat masyarakat menjadi panik, ketakutan, serta memunculkan rasa ketidakpastian terutama setelah diberlakukan lockdown di beberapa daerah. Sebagian orang telah kehilangan pekerjaan

$$
\text { Lingkungan Hidup dan Kebencanaan }
$$


karena dirumahkan sampai pada waktu yang belum pasti. Demikian pula di dunia pendidikan, semua lembaga pendidikan diwajibkan belajar secara jarak jauh melalui media teknologi komunikasi. Kemajuan teknologi belum sepenuhnya dikuasai oleh seluruh lapisan masyarakat, termasak tenaga pendidik yanng tersebar di seluruh pelosok negeri. Dan masih banyak lagi permasalahan-permasalahan sosial yang perlu dibantu pemecahannya (LPPM UNS, 2020).

Pengetahuan tentang COVID-19 ini masih terbatas dan berkembang terus. Kegiatan Kuliah Kerja Nyata $(\mathrm{KKN})$ sebagai kegiatan pengabdian masyarakat, dapat menjadi wahana mengamalkan ilmu pengetahuan dan teknologi, serta seni bagi pemecahan masalah dan kebutuhan masyarakat dalam menghadapi pandemi Covid-19 ini. Kegiatan KKN mahasiswa dapat menjadi alternatif untuk membantu menyebarkan informasi mengenai pandemi Covid-19 ini (Yanti dkk., 2020).

BTN Griya Nugratama merupakan perumahan di desa Sirnagalih, kecamatan Cilaku. Lokasi perumahan ini berjarak 2 kilometer dari pasar induk kota Cianjur yang merupakan pasar tradisional utama di kota ini dan pasar ini selalu ramai. Perumahan ini juga merupakan perumahan yang cukup padat penduduk dan berbatasan langsung dengan beberapa kampung. Dengan demikian tempat yang strategis ini dapat berpotensi terjadi penyebaran virus Corona karena banyaknya jumlah warga dan tingginya mobilitas warga. Selain itu, dengan diberlakukannya PSBB di Cianjur, masih banyak warga yang belum mematuhi aturan seperti pemakaian masker jika beraktivitas di luar rumah dan juga penerapan physical distancing. Banyaknya hoax dan informasi yang simpang siur mengenai wabah Covid-19 ini juga menjadi perhatian utama agar masyarakat tidak termakan berita yang tidak benar. Sehingga melalui kegiatan KKN Covid-19, diharapkan dapat meningkatkan pemahaman warga di Perumahan Griya Nugratama Cianjur dan sekitarnya ini terkait pentingnya gerakan hygiene dan sanitasi diri serta lingkungan, dan juga meningkatkan kesadaran informasi terkait perkembangan wabah Covid-19.

\section{METODE}

Program kegiatan Kuliah Kerja Nyata (KKN) dilaksanakan mulai dari Mei -Juni 2020 di
BTN Griya Nugratama RT05/RW14, Kecamatan Cilaku, Kabupaten Cianjur, Jawa Barat. Program kegiatan dilakukan secara daring untuk sosialisasi dan penyebaran informasi terkait Covid-19 melalui Instagram dan WhatsApp Group, dan secara langsung dalam pembagian hand sanitizer. Kegiatan yang menggunakan interaksi langsung dilakukan dengan tetap melaksanakan protokol kesehatan yang ditetapkan.

Sosialisasi dan penyebaran informasi terkait Covid-19 dilakukan dengan membuat infografis dan video animasi yang kemudian disebarluaskan. Pembuatan hand sanitizer dilakukan secara mandiri dengan mengikuti panduan yang diterbitkan oleh BPOM, kemudian didokumentasikan dalam bentuk video. Pada program pembuatan jamu bahan yang digunakan ialah gula merah, sereh, jahe, kunyit dan temulawak dan air panas.

\section{HASIL DAN PEMBAHASAN}

\section{Edukasi Daring Pemahaman dan Pencegahan Covid-19}

Edukasi daring dilaksanakan dengan bahasan mengenai informasi terbaru terkait Covid19 dan pencegahannya. Sosialisasi yang dilakukan secara daring bertujuan untuk meminimalkan kontak antar perorangan dan menerapkan physical distancing. Sosialisasi dilakukan dengan menggunakan poster dan video yang menarik. Penyebaran poster juga merupakan partisipasi dari gerakan Relawan Online Covid-19 dari akun Instagram relawanonlinecorona, kknrelawancoviduns dan cyouthfighters. Kemudian untuk video edukasi yang dibuat oleh penulis adalah mengenai New Normal, Herd Immunity, Efektivitas Penggunaan Sabun dan Hand Sanitizer. Program kerja ini berjalan lancar dan mendapatkan respon positif. Warga terlibat aktif dalam sosialisasi dan mulai memahami informasi-informasi terkait Covid19, hal ini dapat diketahui dengan melihat respon dan pertanyaan yang diberikan selama pelaksanaan sosialisasi.

\section{Edukasi Melalui Banner Tentang Pemahaman dan Pencegahan Penyebaran Covid-19}

Edukasi tentang pemahaman dan pencegahan penyebaran Covid-19 juga dilakukan secara luring dengan membuat banner berukuran $1 \mathrm{x}$ 0,8 m di 5 titik di RT 05 BTN Griya Nugratama yang

$$
\text { Lingkungan Hidup dan Kebencanaan }
$$


mudah dilihat oleh warga. Hal ini bertujuan untuk meningkatkan kesadaran masyarakat untuk mematuhi protokol kesehatan yang ditetapkan pemerintah sehingga penyebaran Covid-19 dapat diminimalisir.

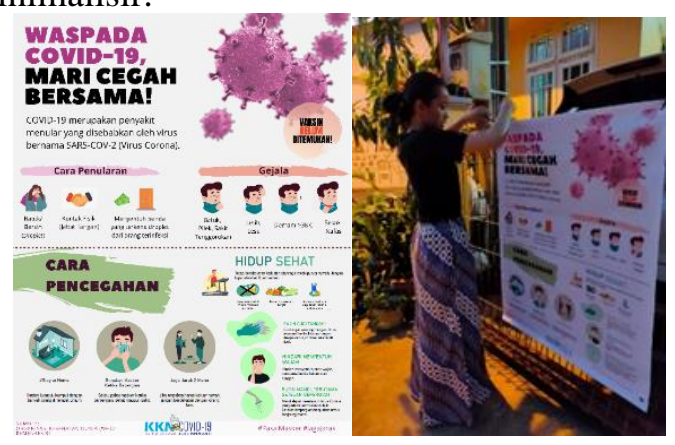

Gambar 1. Pemasangan Banner Tentang Pemahaman dan Pencegahan Penyebaran Covid-19

\section{Pembuatan dan Pembagian Hand Sanitizer}

Pembuatan dan pembagian hand sanitizer kepada warga BTN Griya Nugratama RT 05 bertujuan untuk membiasakan warga dalam menjaga kebersihan diri dalam situasi pandemi Covid-19 ini. Pembuatan hand sanitizer yang sesuai BPOM RI dan WHO ini juga didokumentasikan dalam bentuk video yang kemudian diposting melalui media Instagram. Pembagian hand sanitizer disertai dengan pamflet yang berisikan informasi mengenai cara penggunaan hand sanitizer yang disarankan oleh Organisasi Kesehatan Dunia (WHO) dan juga Kemenkes RI.

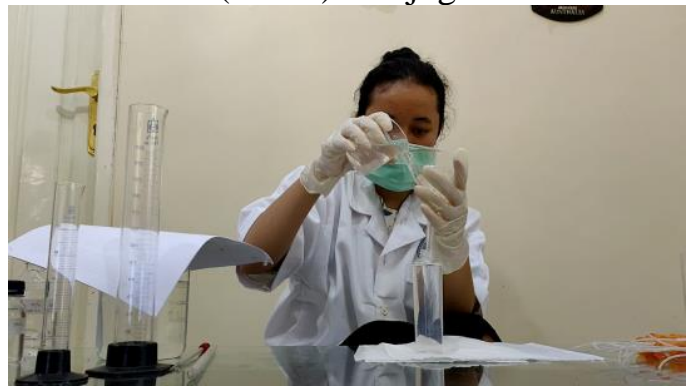

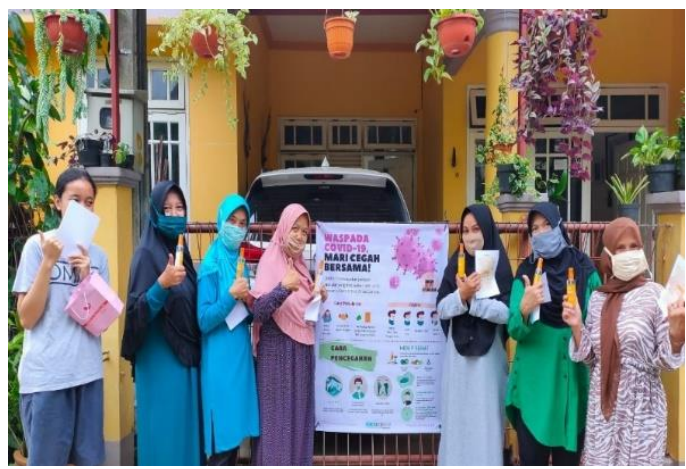

Gambar 2. Pembuatan dan Pembagian Hand Sanitizer

\section{Pembuatan Video Pembuatan Jamu}

Video pembuatan jamu sebagai salah satu program kerja KKN ini merupakan program yang dilakukan sebagai alternatif usaha peningkatan imunitas tubuh sekaligus menumbuhkan kembali kebiasaan konsumsi jamu sebagai warisan budaya Indonesia. Bahan-bahan yang digunakan adalah gula merah, sereh, jahe, kunyit dan temulawak; yang memiliki khasiat untuk meningkatkan imunitas tubuh dan mengobati beberapa penyakit berdasarkan formularium dari Kemenkes RI. Video tutorial pembuatan jamu ini selanjutnya disebarkan melalui sosial media.

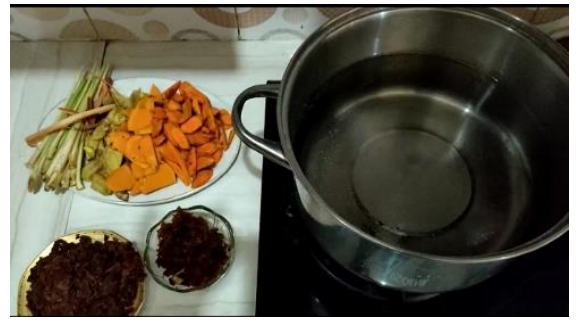

Gambar 3. Proses Pembuatan Jamu

Kegiatan yang telah dilakukan selama program KKN disosialisasikan melalui media tulis di laman berikut https://www.kompasiana.com/aida99370 /5f36184ed541df5bdf40c603/kkn-covid-19-uns-didaerah-masing-masing\#. Sedangkan video kegiatan belum disampaikan via channel Youtube. Sosialisasi tersebut dilakukan agar semua proses kegiatan KKN dapat selalu dipelajari oleh masyarakat dan bermanfaat terus selama tayangan dan tulisan tersebut dibaca dan ditonton oleh masyarakat luas. 


\section{KESIMPULAN}

Situasi pandemi seperti sekarang ini tidak membuat UNS Surakarta menghentikan produktivitasnya. Ditengah ketatnya kebijakan pemerintah atas pencegahan penyebaran virus Covid-19, UNS tetap menyelenggarakan Program KKN Tanggap Covid-19. KKN ini dilaksanakan di seluruh wilayah tempat tinggal mahasiswa di seluruh Indonesia yang telah memenuhi syarat. Mahasiswa yang bertugas berfokus pada tema besar "Supporting Pemahaman Masyarakat Terhadap Covid-19" dengan empat program kerja yaitu edukasi via daring, edukasi via luring (banner), pembuatan dan pembagian hand sanitizer, dan pembuatan jamu untuk alternatif peningkatan imunitas tubuh.

\section{UCAPAN TERIMAKASIH}

Ucapan terima kasih disampaikan kepada Lembaga Penelitian dan Pengabdian Masyarakat (LPPM) Universitas Sebelas Maret Surakarta yang telah memberikan kesempatan untuk melaksanakan Kuliah Kerja Nyata (KKN) Relawan Tanggap Bencana COVID-19. Selain itu juga diucapkan terimakasih kepada Bapak Yayat selaku Ketua RT 05 yang telah mengizinkan berlangsungnya program Kuliah Kerja Nyata di lingkungan BTN Griya Nugratama serta kepada masyarakat sekitar atas partisipasinya dalam program kerja KKN UNS Tanggap COVID 19.

\section{REFERENSI}

BNPB. 2020. Gugus Tugas Percepatan Penanganan Covid-19. https://covid19.go.id/

Kemenkes RI. 2020. Pedoman Pencegahan dan Pengendalian Coronavirus Deseas (Covid 19). http://www.kemenkes.go.id

LPPM UNS. 2020. Buku Saku KKN UNS: Relawan Tanggap Bencana Covid-19. Universitas Sebelas Maret. Surakarta.

Muhammad, Dimas R. A. 2020. Pola Makan Sehat dan Bergizi untuk Meningkatkan Imunitas saat Terserang Covid-19. HUMAS UNS. https://uns.ac.id/id/

Yanti, B., Herry P., dan T. Zulfikar. 2020. Sosialisasi Waspada Infeksi Corona Virus pada Lansia di Panti Jompo Rumoh Seujahtra Geunaseh Sayang, Dinas Sosial Aceh. MARTABE: Jurnal Pengabdian Masyarakat 3(1): 67-72

Yunus NR, dan Annissa R. 2020. Kebijakan Pemberlakuan Lockdown Sebagai Antisipasi Penyebaran Corona Virus COVID-19. Jurnal Sosial \& Budaya 7(3): 227-238. 